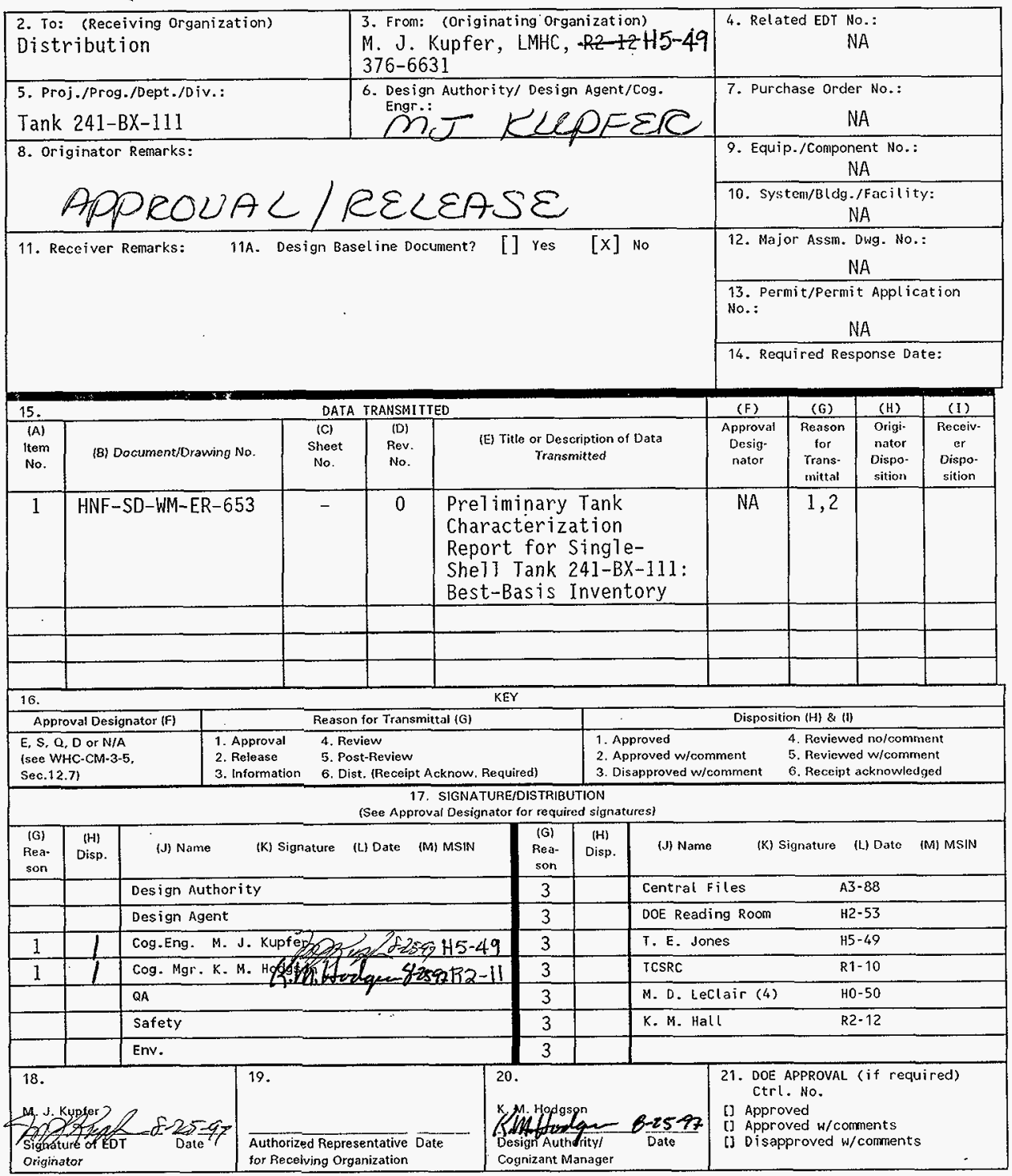




\section{Preliminary Tank Characterization Report for Single-Shell Tank 241-BX-111: Best-Basis Inventory}

M. J. Kupfer (LMHC) and T. E. Jones (Meier Associates)

Lockheed Martin Hanford Corporation, Richland, WA 99352

U.S. Department of Energy Contract DE-AC06-96RL13200

$\begin{array}{ll}\text { EDT/ECN: } & 161475 \\ \text { Org Code: } 74640 & \text { UC: } 712 \\ \text { Charge Code: N4G3A }\end{array}$

B\&R Code: EW3120074 Total Pages: J3

Key Words: TCR, best-basis inventory

Abstract: An effort is underway to provide waste inventory estimates that will serve as standard characterization source terms for the various waste management activities. As part of this effort, an evaluation of available information for single-shel1 tank 241-BX-111 was performed, and a best-basis inventory was established. This work follows the methodology that was established by the standard inventory task.

TRADEMARK DISCLAIMER. Reference herein to any specific commercial product, process, or service by trade name, trademark, manufacturer, or otherwise, does not necessarily constitute or imply its endorsement, recommendation, or favoring by the United States Government or any agency thereof or its contractors or subcontractors.

Printed in the United States of America. To obtain copies of this document, contact: Document Control Services, P.O. Box 950, Mailstop H6-08, Richland WA 99352, Phone (509) 372-2420; Fax (509) 376-4989.
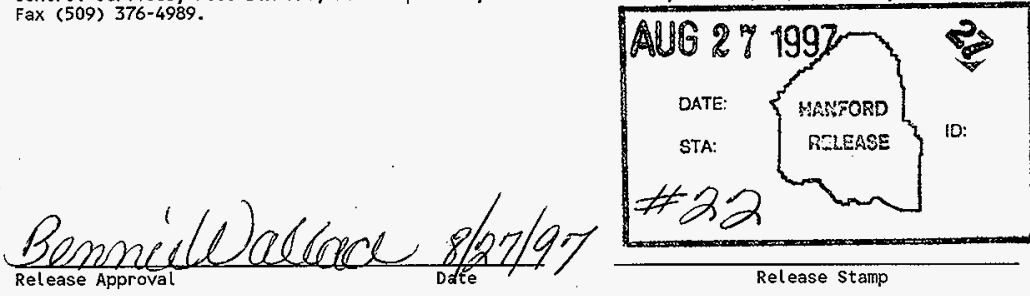

Release Stamp 


\title{
PRELIMINARY TANK CHARACTERIZATION REPORT FOR SINGLE-SHELL TANK 241-BX-111: BEST-BASIS INVENTORY
}

\author{
August 1997 \\ M. J. Kupfer \\ Lockheed Martin Hanford Corporation \\ Richland, Washington
}

T. E. Jones

Meier Associates

Richland, Washington

Prepared for

U.S. Department of Energy

Richland, Washington 
HNF-SD-WM-ER-653

Revision 0

This page intentionally left blank. 
HNF-SD-WM-ER-653

Revision 0

\section{PRELIMINARY TANK CHARACTERIZATION REPORT FOR SINGLE-SHELL TANK 241-BX-111: BEST-BASIS INVENTORY}

. This document is a preliminary Tank Characterization Report (TCR). It only contains the current best-basis inventory (Appendix D) for single-shell tank 241-BX-111. No TCRs have been previously issued for this tank, and current core sample analyses are not available. The best-basis inventory, therefore, is based on an engineering assessment of waste type, process flowsheet data, early sample data, and/or other available information.

The Standard Inventories of Chemicals and Radionuclides in Hanford Site Tank Wastes (Kupfer et al. 1997) describes standard methodology used to derive the tank-by-tank best-basis inventories. This preliminary TCR will be updated using this methodology when additional data on tank contents become available.

\section{REFERENCE .}

Kupfer, M. J., A. L. Boldt, B. A. Higley, K. M. Hodgson, L. W. Shelton, B. C. Simpson, and R. A. Watrous (LMHC), S. L. Lambert, and D. E. Place (SESC), R. M. Orme (NHC), G. L. Borsheim (Borsheim Associates), N. G. Colton (PNNL), M. D. LeClair (SAIC), R. T. Winward (Meier Associates), and W. W. Schulz (W² S Corporation), 1997, Standard Inventories of Chemicals and Radionuclides in Hanford Site Tank Wastes, HNF-SD-WM-TI-740, Rev. 0, Lockheed Martin Hanford Corporation, Richland, Washington. 
HNF-SD-WM-ER-653

Revision 0

This page intentionally left blank. 
HNF-SD-WM-ER-653

Revision 0

\section{APPENDIX D}

\section{EVALUATION TO ESTABLISH BEST-BASIS INVENTORY FOR SINGLE-SHELL TANK 241-BX-111}


HNF-SD-WM-ER-653

Revision 0

This page intentionally left blank. 
HNF-SD-WM-ER-653

Revision 0

APPENDIX D

EVALUATION TO ESTABLISH BEST-BASIS INVENTORY FOR SINGLE-SHELL TANK 241-BX-111

An effort is underway to provide waste inventory estimates that will serve as standard characterization source ferms for the various waste management activities (Hodgson and LeClair 1996). As part of this effort, an evaluation of available information for single-shell tank 241-BX-111 was performed, and a best-basis inventory was established. This work, detailed in the following sections, follows the methodology established by the standard inventory task.

\section{D1.0 CHEMICAL INFORMATION SOURCES}

There have been no significant sampling events for tank 241-BX-111 that could be used to estimate the chemical and radionuclide inventories.

Available information useful for assessment of tank 241-BX-111 inventories includes the following:

- Analytical data from tank 241-BX-112 (Kupfer and Winward 1997) which is the last tank in the three tank cascade (tanks 241-BX-110, 241-BX-111, and 241-BX-112).

- Analytical data for tank 241-T-104 (DiCenso et al. 1994) which contains one of the waste types from the $\mathrm{BiPO}_{4}$ process assumed to be in tank 241-BX-111.

- Analytical data for tanks that contain the salt cake waste type assumed to be in tank 241-BX-111.

- The predicted tank content inventories from the Hanford Defined Waste (HDW) model (Agnew et al. 1996). 
HNF-SD-WM-ER-653

Revision 0

\section{D2.0 COMPARISON OF COMPONENT INVENTORY VALUES}

The HDW model-based inventory for tank 241-BX-111 is provided in Table D2-1 (Agnew et al. 1996). Sample-based data are not available for computing a valid inventory estimate for comparison with the HDW model estimate. The tank volume used to estimate the HDW model inventory is $799 \mathrm{~kL}$ (211 kgal). The waste volume listed in Hanlon (1996) differs significantly from that reported in Agnew et al. (1996). Hanlon (1996) reports a total waste volume of $613 \mathrm{~kL}$ ( $162 \mathrm{kgal})$ which includes $4 \mathrm{~kL}$ (1 kgal) supernatant with the remaining volume consisting of sludge and salt cake. The HDW model assumes that the waste consists entirely of solids (no supernatant). The waste density used for the HDW model inventory estimate is $1.56 \mathrm{~g} / \mathrm{mL}$. The chemical species in this Appendix are reported without charge designation per the best-basis inventory convention.

Table D2-1. Hanford Defined Waste Model-Based Inventory Estimates for Components. in Tank 241-BX-111 (Agnew et al. 1996).

\begin{tabular}{|c|c|c|c|}
\hline Analyte & $\begin{array}{l}\text { HDW model inventory } \\
\text { estimate }(\mathrm{kg})\end{array}$ & Analyte & $\begin{array}{l}\text { HDW model inventory } \\
\text { estimate (kg) }\end{array}$ \\
\hline $\mathrm{AI}$ & 42,000 & $\mathrm{~Pb}$ & 800 \\
\hline $\mathrm{Bi}$ & 1,300 & $\mathrm{P}$ as $\mathrm{PO}_{4}$ & 15,000 \\
\hline $\mathrm{Ca} \cdot$ & 2,200 & $\mathrm{Si}$ & 1,700 \\
\hline $\mathrm{Cl}$ & 3,100 & $\mathrm{~S}$ as $\mathrm{SO}_{4}$ & 13,000 \\
\hline $\mathrm{Cr}$ & 1,800 & $\mathrm{Sr}$ & 0.21 \\
\hline $\mathrm{F}$ & 1,200 & $\mathrm{TIC}$ as $\mathrm{CO}_{3}$ & 21,000 \\
\hline $\mathrm{Fe}$ & 1,800 & TOC & 4,940 \\
\hline $\mathrm{Hg}$ & 6.3 & $\mathrm{U}_{\text {TOTAL }}$ & 4,200 \\
\hline $\mathrm{K}$ & 1,000 & $\mathrm{Zr}$ & 96 \\
\hline $\mathrm{La}$ & 0.30 & $\mathrm{H}_{2} \mathrm{O}(\mathrm{wt} \%)$ & 42 \\
\hline $\mathrm{Mn}$ & 120 & Density $(\mathrm{kg} / \mathrm{L})$ & 1.56 \\
\hline $\mathrm{Na}$ & 200,000 & \multicolumn{2}{|c|}{ Radiological components ${ }^{\mathrm{a}}(\mathrm{C} \mathrm{i})$} \\
\hline $\mathrm{Ni}$ & 550 & $\mathrm{Pu}$ & 120 \\
\hline $\mathrm{NO}_{2}$ & 56,000 & ${ }^{137} \mathrm{Cs}$ & 150,000 \\
\hline $\mathrm{NO}_{3}$ & 270,000 & ${ }^{90} \mathrm{Sr}$ & 88,000 \\
\hline $\mathrm{OH}$ & 110,000 & & \\
\hline
\end{tabular}

HDW $=$ Hanford Defined Waste, data rounded to two significant figures

aRadionuclides decayed to January 1, 1994. 
HNF-SD-WM-ER-653

Revision 0

\section{D3.0 COMPONENT INVENTORY EVALUATION}

The following evaluation of tank contents is performed to identify potential errors and/or missing information that would have an affect on HDW model component inventories.

\section{D3.1 CONTRIBUTING WASTE TYPES}

The following abbreviations are used to designate waste types:

BYSltCk = Salt cake resulting from in-tank solidification of supernatants (evaporation using in-tank heaters).

$\mathrm{CW}=\mathrm{BiPO}_{4}$ process aluminum cladding waste.

$1 \mathrm{C}=$ first decontamination cycle $\mathrm{BiPO}_{4}$ waste (also contains some $\mathrm{CW}$ which was used to neutralize the $1 \mathrm{C}$ waste).

2C $=$ Second decontamination cycle of the bismuth phosphate process

EB-ITS = Hill et al. (1995) designation for evaporator bottoms. Comparable to BYSltCk.

\section{Reported Waste Types in Tank 241-BX-111}

Anderson (1990), SORWT (Hill et al. 1995): 1C, EB-ITS, CW

Agnew et al. (1996): BYSltCk, 1C

SORWT $=$ Sort on radioactive waste type

Model-Based Prediction of Current Waste Types and Volumes (Agnew et al. 1996)

Waste type

BYSltCk

$1 \mathrm{C} 2$

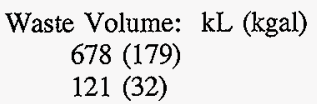

Tank 241-BX-111 is the middle tank in a cascade that includes tanks 241-BX-110 and 241-BX-112. Based on the process history from Anderson (1990) and Agnew et al. (1995) it is expected that $1 \mathrm{C} / \mathrm{CW}$ waste solids fill the bottom of tank 241-BX-111. These solids resulted from the cascade from tank 241-BX-110 from 1950 to 1954 . No other solids contributions are apparent from the transfer records until evaporator bottoms were received from operations of the in-tank solidification (ITS) evaporator unit beginning in 1972. This waste was all received from tank 241-BY-112, and the solids resulting from these operations are designated as BYSltCk by Agnew et al. (1996). Anderson (1990) and Hill et al. (1995) state the presence of CW in the tank from 1965 to 1971 (before receipt of evaporator bottoms from ITS). However, there are no firm records that CW was transferred to the tank nor that solids from this waste (other than those from the $1 \mathrm{C} / \mathrm{CW}$ inventory) exist in the tank. 
HNF-SD-WM-ER-653

Revision 0

Based on close examination of the waste transaction records (Agnew et al. 1995) and waste level measurements reported in Brevick et al. (1996), it is concluded that the Agnew et al. (1996) basis provides a reasonable approximation of the waste volumes and relative proportions of waste types (i.e., $678 \mathrm{~kL}$ [179 kgal] BYSltCk and $121 \mathrm{~kL}$ [32 kgal] 1C waste) in tank 241-BX-111. Full core sampling of this tank would likely be required to verify/dispute the model predictions.

\section{D3.2 EVALUATION OF TECHNICAL FLOWSHEET INFORMATION}

The neutralized waste composition for 1C waste based on the flowsheet defined.in Schneider (1951) is provided in Table D3-1. The Los Alamos National Laboratory (LANL). defined 1C waste stream from Agnew et al. (1996) is also provided for comparison. As shown in Table D3-1 the aluminum concentration in the $1 \mathrm{C}$ defined waste stream from Agnew et al. is approximately. a factor of three higher than for the flowsheet composition. The presence of $\mathrm{Al}$ in the $1 \mathrm{C}$ waste streams is attributed to the addition of aluminumcladding waste in the $\mathrm{BiPO}_{4}$ process facilities to neutralize the $1 \mathrm{C}$ waste stream. Based on information in Schneider (1.951) it is thought that the $1 \mathrm{C}$ waste stream contained approximately $7 \mathrm{vol} \%$ cladding waste, which is about a third of that estimated in Agnew et al. Other component concentrations in the Schneider 1C flowsheet and the LANL defined $1 \mathrm{C}$ waste stream are comparable.

There is no flowsheet basis for salt cake resulting from the ITS units used in the BY Tank Farm that can be compared to the LANL compositions for BYSltCk. Tank waste analyses are available, however, for BY Tank Farm tanks known to contain BYSltCk. These salt cake compositions are compared to the LANL BYSltCk defined waste in Section D3.4.2.

Table D3-1. Technical Flowsheet and Hanford Defined Waste Streams. (2 Sheets)

\begin{tabular}{|c|c|c|}
\hline Analyte & Flowsheet $1 \mathrm{C}^{\mathrm{a}}(M)$ & HDW model $1 \mathrm{C} 2^{\mathrm{b}}(M)$ \\
\hline $\mathrm{NO}_{3}$ & 1.44 & 0.588 \\
\hline $\mathrm{NO}_{2}$ & 0.0577 & 0.174 \\
\hline $\mathrm{Cl}$ & $\mathrm{NR}$ & 0.0154 \\
\hline $\mathrm{SO}_{4}$ & 0.0631 & 0.0616 \\
\hline $\mathrm{PO}_{4}$ & 0.258 & 0.334 \\
\hline $\mathrm{CO}_{3}$ & $\mathrm{NR}$ & 0.0181 \\
\hline $\mathrm{F}$ & 0.170 & 0.228 \\
\hline $\mathrm{Bi}$ & 0.0115 & 0.014 \\
\hline $\mathrm{Fe}$ & 0.0315 & 0.046 \\
\hline $\mathrm{Mn}$ & $\mathrm{NR}$ & 0 \\
\hline $\mathrm{Si}$ & 0.0312 & 0.038 \\
\hline
\end{tabular}


HNF-SD-WM-ER-653

Revision 0

Table D3-1. Technical Flowsheet and Hanford Defined Waste Streams. (2 Sheets)

\begin{tabular}{|c|c|c|}
\hline Analyte & Flowsheet $1 \mathrm{C}^{\mathrm{a}}(M)$ & HDW model $1 \mathrm{C}^{\mathrm{b}}(M)$ \\
\hline $\mathrm{U}$ & $9.63 \cdot \mathrm{E}-04$ & $7.00 \mathrm{E}-04$ \\
\hline $\mathrm{Cr}^{+3 /+6}$ & 0.00306 & 0.0052 \\
\hline $\mathrm{Ce}$ & $1.93 \mathrm{E}-04$ & $\mathrm{NR}$ \\
\hline $\mathrm{Na}$ & 2.17 & 2.17 \\
\hline $\mathrm{K}$ & $\mathrm{NR}$ & 0.0034 \\
\hline $\mathrm{Hg}$ & $\mathrm{NR}$ & $2 \mathrm{E}-05$ \\
\hline $\mathrm{Zr}$ & $2.96 \mathrm{E}-04$ & 0.004 \\
\hline $\mathrm{Al}$ & 0.0826 & 0.233 \\
\hline
\end{tabular}

HDW $=$ Hanford Defined Waste

$\mathrm{NR}=$ Not reported

${ }^{a}$ Appendix C of Kupfer et al. (1997) and Schneider (1951). Assumes 1C waste contains approximately 7 percent $\mathrm{CW}$

${ }^{\mathrm{b}}$ Appendix B of Agnew et al. (1996). Assumes 1C waste contains approximately 24 percent $\mathrm{CW}$.

\section{D3.3 ASSUMPTIONS FOR RECONCILING WASTE INVENTORIES}

Reference inventories of components in tank 241-BX-111 were estimated using an engineering assessment that is based on a set of simplified assumptions. The predicted inventories were then compared with the HDW model inventories. The assumptions and observations for the engineering assessment were based on best technical judgement pertaining to input information that can significantly influence tank inventories. This includes: (1) prediction of contributing waste types, and relative proportions of the waste types, (2) predictions of flowsheet conditions, fuel processed, and waste volumes, (3) prediction of partitioning of components, and (4) predictions of physical parameters such as density, percent solids, etc. By using this evaluation the assumptions can be modified as necessary to provide a basis for identifying potential errors and/or missing information that could influence the sample- and model-based inventories. The following are simplified assumptions and observations used for the evaluation.

- The $1 \mathrm{C}$ and BYSltCk waste streams contributed to solids formation (Agnew et al. 1996). The $1 \mathrm{C}$ waste stream contained $7 \mathrm{vol} \%$ of $\mathrm{CW}$ from the $\mathrm{BiPO}_{4}$ process (Schneider 1951).

- The analytical data for tanks 241-BX-112 (Kupfer and Winward 1997) and 241-T104 (DiCenso et al. 1994), which contain only the $1 \mathrm{C}$ waste type, helped provide the analytical basis for estimating the inventory in tank 241-BX-111. 'The 
HNF-SD-WM-ER-653

Revision 0

analytical data for BY Tank Farm salt cake in tanks 241-BY-105, 241-BY-106, and 241-BY-110 helped provide the basis for estimating the inventory for salt cake components in tank 241-BX-111.

The volumes of the assumed waste types are $121 \mathrm{~kL}(32 \mathrm{kgal}) 1 \mathrm{C}$ waste and $678 \mathrm{~kL}$ (179 kgal) BYSltCk (Agnew et al. 1996).

\section{D3.4 METHODOLOGY FOR ESTIMATING TANK 241-BX-111 WASTE INVENTORY}

There are no appropriate samples for tank 241-BX-111 that could be used to estimate tank waste component inventories. In addition the process history for this tank is not adequately defined to enable an estimate of waste component inventories. However, the assumed waste types in tank 241-BX-111 (1C and BYSltCk) have been sufficiently characterized in other tanks to allow use of this information as a basis for estimating the inventory in tank 241-BX-111. Thus, inventories calculated for tanks 241-T-104 and 241-BX-112 (1C waste), and three tanks containing (241-BY-105, 241-BY-106, and 241-BY-110) BYSltCk provided the basis for the independent assessment of the tank 241-BX-111 inventory.

Some caution should be used in assuming that the chemical composition for a particular waste type in one tank can be used for that waste type in other tanks. Although this assumption has been shown to be valid for some tanks, particularly for those in a cascade arrangement, component concentrations in a particular waste type may not always be comparable to other waste tanks due to the large variation in the waste volumes flowing through the tanks, variations in solids and liquid ratios resulting from cascade and cribbing procedures, and also because of potential for chemical reactions (e.g., metathesis) of components when mixed/diluted with other waste types. However, without suitable analytical data and/or process history records for tank 241-BX-111, this method was used as the basis for predicting the tank inventory.

\section{D3.4.1 Methodology for 1C Waste}

One method for estimating a component inventory for a particular waste type in a tank (i.e., 1C waste) is to derive a concentration factor (CF) for that component. This approach was used to estimate inventories in tank 241-T-104 as well as tank 241-BX-112 that is in the same cascade as tanks 241-BX-110 and 241-BX-111. Concentration factors are a means of reconciling process-based information and sample-based information for particular waste types: The CF is derived by dividing the concentration of a component found in the tank samples by the concentration of that component in the neutralized process waste stream (i.e., flowsheet concentrations in Table D3-1). The relative concentrations of components expected to precipitate essentially 100 percent to the waste solids (e.g., $\mathrm{Bi}, \mathrm{Fe}$, and $\mathrm{Zr}$ ) should be approximately proportional to the respective flowsheet concentrations for those 
components; i.e., these components should exhibit nearly the same CFs. If this is the case, it can generally be concluded that the sample data are consistent with the flowsheet basis and thus, represent the tank contents. Since the CFs are often consistent for the same waste type in different tanks, inventories for components in tanks that do not have samples (e.g., tank 241-BX-111) can be estimated if it is known that the defined waste is indeed present in the tank, and the volume of the defined waste is known or can be predicted.

The CFs are quite different for different waste types. For example the $\mathrm{CF}$ based on $\mathrm{Bi}$ for the $\mathrm{BiPO}_{4}$ process 224 waste is 95 and for $2 \mathrm{C}$ waste the $\mathrm{CF}$ is approximately 20 .

The following procedure is used to calculate the $\mathrm{CF}$ for $\mathrm{Bi}$ for $1 \mathrm{C}$ waste in tank 241-BX-112. The analytical-based inventory for $\mathrm{Bi}$ is $14,200 \mathrm{~kg}$ (Kupfer and Winward 1997) which corresponds to a Bi concentration in the solids of $0.110 M$. The flowsheet concentration for $\mathrm{Bi}$ is $0.0115 \mathrm{M}$ (Table $\mathrm{D} 3-1)$. $\mathrm{The}_{\mathrm{CF}}$ is:

$$
\frac{0.110 \text { moles } \mathrm{Bi} / \mathrm{L}}{0.0115 \text { moles } \mathrm{Bi} / \mathrm{L}}=9.5
$$

Calculated CFs for components in $1 \mathrm{C}$ waste for tanks 241-BX-112 and 241-T-104 that are expected to fully precipitate, range from 9 to $12(\mathrm{Bi}, \mathrm{Si}, \mathrm{Zr}, \mathrm{Ce}$, and $\mathrm{Cr}$ ). Based on known chemistry of these components in alkaline solutions it is expected that the components do indeed precipitate approximately 100 percent and the variation in CFs is due to some sample heterogeneity and/or laboratory analytical error. For the most part these $\mathrm{CFs}$ are considered consistent which indicates that the samples likely represent the $1 \mathrm{C}$ flowsheet (Table D3-1) basis for the wastes.

Once the CFs for fully precipitated components for a waste type are determined, the sample analysis can be used to establish how other components such as $\mathrm{SO}_{4}$ or $\mathrm{PO}_{4}$ partition between solids and supernatants. Concentration factors for components not expected to precipitate 100 percent can be ratioed to $\mathrm{CF}_{\mathrm{Bi}}$ to obtain the partitioning factors (PFs) for those components. The $\mathrm{PF}$ for any component $\mathrm{N}$, defined as $\mathrm{CF}_{\mathrm{N}} / \mathrm{CF}_{\mathrm{Bi}}$, is the fraction of $\mathrm{N}$ partitioned to the sludge.

Thus the $\mathrm{PF}$ for $\mathrm{PO}_{4}(241-\mathrm{BX}-112)=\frac{\mathrm{CF}_{\mathrm{PO} 4}}{\mathrm{CF}_{\mathrm{Bi}}}=\frac{3.2}{9.5}=0.34$

i.e., $0.34(100)=34$ percent of the $\mathrm{PO}_{4}$ partitions to the solids.

Using this method, the estimated PFs for other components for $1 \mathrm{C}$ waste based on tank 241-BX-112 are shown in Table D3-2. 
HNF-SD-WM-ER-653

Revision 0

Table D3-2. Partition Factors for 1C Waste Components in Tank 241-BX-112.

\begin{tabular}{|c|c|}
\hline $\mathrm{AI}$ & 0.84 \\
\hline $\mathrm{F}$ & 0.45 \\
\hline $\mathrm{Fe}$ & 0.74 \\
\hline $\mathrm{Na}$ & 0.23 \\
\hline $\mathrm{NO}_{2}$ & 0.2 \\
\hline $\mathrm{NO}_{3}$ & 1.34 \\
\hline $\mathrm{PO}_{4}$ & 0.34 \\
\hline $\mathrm{SO}_{4}$ & 0.15 \\
\hline $\mathrm{U}$ & 0.62 \\
\hline
\end{tabular}

In general, these PFs also are quite comparable to those found in tank 241-T-104. Several anomalies are apparent for tank 241-BX-112; e.g., the PFs for $\mathrm{Al}$ and $\mathrm{NO}_{2}$ are surprisingly high. Based on the analytical data, it could be concluded that these components are essentially fully precipitated. It was also unexpected that both Fe and $U$ apparently partition between the solids and supernatant. Possible explanations for these unexpected conclusions are summarized in Section D3.6.

The calculated CFs and PFs for tanks 241-BX-112 and 241-T-104 provide significant confidence that the analytical data for the tanks are representative of the tank contents and could be used as a basis for component inventories in tank 241-BX-111. This is substantiated by the following:

- CFs for components that are expected to fully precipitate are quite consistent which indicates that the samples likely represent the $1 \mathrm{C}$ flowsheet basis for the waste.

- The PFs indicate reasonable partitioning of components based on experience and knowledge of the typical chemical behavior of the components in alkaline media (except for nitrite).

\section{D3.4.2 Methodology for Salt Cake Waste}

BY Tank Farm salt cake (BYSltCk), the abbreviation used by Agnew et al. (1996), is representative of salt waste supernatants that are evaporated and concentrated using in-tank heaters. In-tank solidification campaigns were performed in the BY Tank Farm from 1964 
HNF-SD-WM-ER-653

Revision 0

through 1976: waste supernatants that were evaporated originated primarily from the $\mathrm{BiPO}_{4}$ process operations in B Plant. Heaters were placed in tanks 241-BY-101, 241-BY-102 and 241-BY-112. Certain BY Tank Farm tanks were designated as feed tanks. Concentrates from the heated tanks were transferred to other tanks in the BY Tank Farm and some BX Tank Farm tanks where they cooled and crystallized (Agnew et al. 1995)

A defined waste composition for BYSltCk is provided in Agnew et al. (1996). Because of the complicated waste supernatant transfer history of feed to the ITS campaign and, the lack of a flowsheet basis for the waste, it is difficult to perform an independent assessment to estimate a salt cake composition that can be compared to the model-based BYSltCk composition. However, some samples from several BY Tank Farm tanks containing BYSltCk have been analyzed and reported. Table D3-3 summarizes the compositions of salt cake from tanks 241-BY-105, 241-BY-110 and 241-BY-106 based on segment-level analysis reported, respectively, in Simpson et al. (1996a and b) and Bell et al. (1996). Also shown are the average concentrations of waste components for the BY Tank Farm salt cake in those tanks: For comparison, the BYSltCk defined waste composition from Agnew et al. (1996) is also shown.

Table D3-3. Concentrations of Components in BY Tank Farm Salt Cake Samples ${ }^{e}(\mu \mathrm{g} / \mathrm{g})$. (2 Sheets).

\begin{tabular}{|c|c|c|c|c|c|}
\hline Analyte & $241-\mathrm{BY}-105^{\mathrm{a}}$ & $241-\mathrm{BY}-106^{\circ}$ & $241-\mathrm{BY}-110^{\mathrm{c}}$ & $\begin{array}{c}\text { Average } \\
\text { concentration }\end{array}$ & BYSltCk $^{\mathrm{d}}$ \\
\hline $\mathrm{Ag}$ & 17.4 & 14.5 & 17.5 & 16.5 & $\mathrm{NR}$ \\
\hline $\mathrm{AI}$ & 18,400 & 20,400 & 14,100 & 17,633 & 35,800 \\
\hline $\mathrm{Bi}$ & 55.6 & $\mathrm{NR}$ & $\mathrm{NR}$ & 55.6 & 116 \\
\hline $\mathrm{B}$ & $\mathrm{NR}$ & 113 & 92.3 & 103 & $\mathrm{NR}$ \\
\hline $\mathrm{Cd}$ & 6.54 & 8.25 & 21.1 & 12.0 & $\mathrm{NR}$ \\
\hline $\mathrm{Ca}$ & 216 & 308 & 400 & 308 & 1,820 \\
\hline $\mathrm{Cl}$ & 897 & 2,060 & 2,250 & 1,736 & 2,780 \\
\hline $\mathrm{Cr}$ & 321 & 855 & 2,900 & 1,359 & 1,630 \\
\hline $\mathrm{Co}$ & 8.75 & $\mathrm{NR}$ & $\mathrm{NR}$ & 8.75 & $\mathrm{NR}$ \\
\hline $\mathrm{Cu}$ & 7.57 & $\mathrm{NR}$ & $\mathrm{NR}$ & 7.57 & $\mathrm{NR}$ \\
\hline $\mathrm{F}$ & 4,100 & 5,130 & 5,420 & 4,883 & 700 \\
\hline $\mathrm{Fe}$ & 476 & 215 & 924 & 538 & 554 \\
\hline $\mathrm{Pb}$ & 50.3 & 64.5 & 130 & 82 & 726 \\
\hline $\mathrm{Mn}$ & 54.8 & 9.57 & 52.8 & 39.1 & 110 \\
\hline $\mathrm{Na}$ & 198,000 & 203,000 & 237,000 & 212,667 & 176,000 \\
\hline $\mathrm{Ni}$ & 75.9 & 47.9 & 193 & 106 & 490 \\
\hline
\end{tabular}


HNF-SD-WM-ER-653

Revision 0

Table D3-3. Concentrations of Components in BY Tank Farm Salt Cake Samples $^{\mathrm{e}}(\mu \mathrm{g} / \mathrm{g})$. (2 Sheets)

\begin{tabular}{|c|c|c|c|c|c|}
\hline Analyte & $241-B Y-105^{a}$ & $241-B Y-106^{b}$ & $241-B Y-110^{\circ}$ & $\begin{array}{c}\text { Average } \\
\text { concentration }\end{array}$ & BYSltCk $^{\mathrm{d}}$ \\
\hline $\mathrm{NO}_{3}$ & 491,000 & 329,000 & 184,000 & 335,000 & 246,000 \\
\hline $\mathrm{NO}_{2}$ & 9,410 & 32,100 & 30,600 & 24,037 & 49,500 \\
\hline Oxalate & 11,300 & 8,990 & 13,600 & 11,297 & 0.15 \\
\hline $\mathrm{PO}_{4}$ & 4,890 & 5,270 & 14,200 & 8,120 & 4,020 \\
\hline $\mathrm{OH}$ & NR & $\mathrm{NR}$ & $\mathrm{NR}$ & NR & 96,700 \\
\hline $\mathrm{K}$ & 712 & 2,470 & 1,930 & 1,704 & 910 \\
\hline $\mathrm{Si}$ & 180 & 184 & 451 & 272 & 1,360 \\
\hline $\mathrm{SO}_{4}$ & 10,600 & 11,300 & 18,400 & 13,433 & 11,400 \\
\hline $\mathrm{Sr}$ & 88.3 & 44.4 & 58.1 & 64 & 0.20 \\
\hline $\mathrm{CO}_{3}$ & NR & 36,800 & 159,000 & 97,900 & 18,600 \\
\hline TOC & 3,250 & 2,500 & 5,920 & 3,890 & 4,515 \\
\hline $\mathrm{U}$ & 261 & 164.2 & 697 & 374 & 3,790 \\
\hline $\mathrm{Zr}$ & 5.23 & 6.28 & 14.4 & 8.64 & 16.7 \\
\hline Density $(\mathrm{g} / \mathrm{mL})$ & NR & 1.71 & $\mathrm{NR}$ & 1.71 & 1.62 \\
\hline $\mathrm{H}_{2} \mathrm{O} \mathrm{wt} \%$ & 16.1 & 25.5 & 23.2 & 21.6 & 37.4 \\
\hline \multicolumn{6}{|c|}{ Radionuclides $^{\S}(\mu \mathrm{Ci} / \mathrm{g})$} \\
\hline${ }^{137} \mathrm{Cs}$ & NR & 106 & 60 & 83 & 133 \\
\hline${ }^{90} \mathrm{Sr}$ & NR & NR & 22 & 22 & 80 \\
\hline${ }^{239 / 240} \mathrm{Pu}$ & NR & NR & 0.019 & 0.019 & 0.11 \\
\hline
\end{tabular}

$\mathrm{NR}=$ Not reported

a Simpson et al. (1996a)

${ }^{\mathrm{b}}$ Bell et al. (1996)

'Simpson et al. (1996b)

${ }^{d}$ Agnew et al. (1996).

${ }^{e}$ Less than values were not included in this analysis

${ }^{\mathrm{f}}$ Radionuclides are reported as of the sample analysis date.

As indicated in Table D3-3, the concentrations of major waste components such as $\mathrm{Na}$, $\mathrm{Al}, \mathrm{NO}_{3}, \mathrm{PO}_{4}$, and $\mathrm{SO}_{4}$ vary between tanks by no more than an approximate factor of three. However, the variation between tanks for minor components is much higher. 
HNF-SD-WM-ER-653

Revision 0

The average composition based on sample analyses compares within approximately a factor of two with the predicted BYSltCk composition major components from the HDW model. For this engineering assessment the average analytical-based composition from tanks 241-BY-105, 241-BY-106, and 241-BY-110 will be used for estimating the composition of the salt cake in tank 241-BX-111.

\section{D3.5 ESTIMATED COMPONENT INVENTORIES}

Following are the calculational bases and example calculations for estimating component inventories in tank 241-BX-111.

\section{D3.5.1 Inventory Estimates for 1C Waste}

Inventories for components in the $1 \mathrm{C}$ waste type in tank $241-\mathrm{BX}-111$ were based on the CFs and PFs derived from tanks 241-T-104 and 241-BX-112. Since tank 241-BX-111 is in the cascade series with tank 241-BX-112 and since both tanks received $1 \mathrm{C}$ waste directly from B Plant $\mathrm{BiPO}_{4}$ process, the CFs and PFs derived from the analytical data for tank 241-BX-112 (Kupfer and Winward 1997) were used to calculate the inventories of tank 241BX-111. These sludge inventories are shown in D3-4.

Inventory of Components That Precipitate Approximately 100 Percent (Bi, Si, Zr, $\mathrm{Ce}$, and $\mathrm{Cr}$ )

Inventories of components that precipitate 100 percent were calculated using a $\mathrm{CF}$ of 9.5 based on $\mathrm{Bi}$. For components that partition, the PFs listed in Table D3-2 for tank 241-BX-112 were used.
Bi: $\quad 0.0115$ moles $B i / L_{1 C} \times 9.5_{C R} \times 121 \mathrm{~kL}_{1 C} \times 1,000 \mathrm{~L} / \mathrm{kL} \times 209 \mathrm{~g} /$ mole Bi $\mathrm{x} \mathrm{kg} / 1.0 \mathrm{E}+03 \mathrm{~g}=2,760 \mathrm{~kg}$
Si: $\quad 0.0312$ moles Si $/ \mathrm{L}_{1 \mathrm{C}} \times 9.5_{\mathrm{CF}} \times 121 \mathrm{~kL}_{1 \mathrm{C}} \times 1,000 \mathrm{~L} / \mathrm{kL} \times 28.1 \mathrm{~g} / \mathrm{mole} \mathrm{Si}$ $\mathrm{x} \mathrm{kg} / 1.0 \mathrm{E}+03 \mathrm{~g}=1,010 \mathrm{~kg}$
Similarly
$\begin{array}{ll}\mathrm{Zr}: & 31.0 \mathrm{~kg} \\ \mathrm{Ce}: & 31.1 \mathrm{~kg} \\ \mathrm{Cr}: & 183 \mathrm{~kg}\end{array}$ 
HNF-SD-WM-ER-653

Revision 0

Inventory of Components that Partition Between Liquid and Solid Phases $(\mathrm{Na}, \mathrm{Al}$, $\mathrm{Fe}, \mathrm{U}, \mathrm{NO}_{3}, \mathrm{NO}_{2}, \mathrm{SO}_{4}, \mathrm{PO}_{4}$, and $\mathrm{F}$ )

Na: $\quad 2.17$ moles $\mathrm{Na} / \mathrm{L}_{\mathrm{ic}} \times 9.5_{\mathrm{CF}} \times 0.23 \mathrm{PF} \times 121 \mathrm{~kL} \times 1,000 \mathrm{~L} / \mathrm{kL} \times$ $23 \mathrm{~g} / \mathrm{mole} \mathrm{Na} \times \mathrm{kg} / 1.0 \mathrm{E}+03 \mathrm{~g}=13,000 \mathrm{~kg}$

Al: $\quad 0.0826$ moles $\mathrm{Al} / \mathrm{L}_{1 \mathrm{C}} \times 9.5_{\mathrm{CP}} \times 0.84 \mathrm{PF} \times 121 \mathrm{~kL} \times 1,000 \mathrm{~L} / \mathrm{kL} \times$

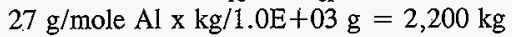

Similarly

Fe: $\quad 1,500 \mathrm{~kg}$

U: $\quad 166 \mathrm{~kg}$

$\mathrm{NO}_{3}: \quad 12,300 \mathrm{~kg}$

$\mathrm{NO}_{2}: \quad 4,030 \mathrm{~kg}$

$\mathrm{SO}_{4}: \quad 1,040 \mathrm{~kg}$

$\mathrm{PO}_{4}: \quad 9,580 \mathrm{~kg}$

F: $\quad 1,670 \mathrm{~kg}$

Table D3-4. Estimated Concentrations of Tank 241-BX-111 Sludge. (2 Sheets)

\begin{tabular}{|c|c|c|c|c|}
\hline Analyte & $\begin{array}{c}241-\mathrm{BX}-112 \\
\text { inventory } \\
(\mathrm{kg})\end{array}$ & $\begin{array}{c}\text { Analytical-based } \\
\text { sludge inventory }^{\text {estimate }}(\mathrm{kg})\end{array}$ & $\begin{array}{c}\text { Concentration factor- } \\
\text { based sludge inventory } \\
\text { estimate }^{\mathrm{c}}(\mathrm{kg})\end{array}$ & $\begin{array}{c}\text { Engineering-based } \\
\text { sludge inventory }^{\mathrm{e}} \\
\text { stimate }^{\mathrm{d}}(\mathrm{kg})\end{array}$ \\
\hline $\mathrm{Al}$ & 11,100 & 2,150 & 2,200 & 2,150 \\
\hline $\mathrm{Bi}$ & 14,200 & 2,760 & 2,760 & 2,760 \\
\hline $\mathrm{Ca}$ & 2,040 & 396 & $\mathrm{NR}$ & 396 \\
\hline $\mathrm{Cl}$ & 860 & 167 & $\mathrm{NR}$ & 167 \\
\hline $\mathrm{Cr}$ & 1,050 & 204 & 183 & 204 \\
\hline $\mathrm{F}$ & 8,700 & 1,690 & 1,670 & 1,690 \\
\hline $\mathrm{Fe}$ & 7,700 & 1,490 & 1,500 & 1,490 \\
\hline $\mathrm{Pb}$ & $<269$ & $<52.2$ & $\mathrm{NR}$ & $<52$ \\
\hline $\mathrm{Mn}$ & 263 & 51.0 & $\mathrm{NR}$ & 51 \\
\hline $\mathrm{Na}$ & 66,800 & 13,000 & 13,000 & 13,000 \\
\hline $\mathrm{Ni}^{\mathrm{Ni}}$ & $<2.26$ & $<0.44$ & $\mathrm{NR}$ & $<0.44$ \\
\hline $\mathrm{NO}_{3}$ & 61,500 & 11,900 & 12,300 & 11,900 \\
\hline $\mathrm{NO}_{2}$ & 20,900 & 4,050 & 4,030 & 4,050 \\
\hline
\end{tabular}


HNF-SD-WM-ER-653

Revision 0

Table D3-4. Estimated Concentrations of Tank 241-BX-111 Sludge. (2 Sheets)

\begin{tabular}{|c|c|c|c|c|}
\hline Analyte & $\begin{array}{c}241-\mathrm{BX}-112 \\
\text { inventory } \\
(\mathrm{kg})\end{array}$ & $\begin{array}{c}\text { Analytical-based } \\
\text { sludge inventory } \\
\text { estimate }^{\mathrm{b}}(\mathrm{kg})\end{array}$ & $\begin{array}{c}\text { Concentration factor- } \\
\text { based sludge inventory } \\
\text { estimate }{ }^{\mathrm{c}}(\mathrm{kg})\end{array}$ & $\begin{array}{c}\text { Engineering-based } \\
\text { sludge inventory } \\
\text { estimate }^{\mathrm{d}}(\mathrm{kg})\end{array}$ \\
\hline $\mathrm{PO}_{4}$ & 48,100 & 9,330 & 9,580 & 9,330 \\
\hline $\mathrm{OH}$ & $\mathrm{NR}$ & $\mathrm{NA}$ & $\mathrm{NR}$ & $\mathrm{NR}$ \\
\hline $\mathrm{K}$ & 382 & 74.1 & $\mathrm{NR}$ & 74.1 \\
\hline $\mathrm{Si}$ & 6,830 & 1,320 & 1,010 & 1,320 \\
\hline $\mathrm{SO}_{4}$ & 5,300 & 1,030 & 1,040 & 1,030 \\
\hline $\mathrm{Sr}$ & 107 & 20.8 & $\mathrm{NR}$ & 20.8 \\
\hline $\mathrm{CO}_{3}$ & 8,800 & 1,710 & $\mathrm{NR}$ & 1,710 \\
\hline${ }_{\mathrm{TOC}}$ & 780 & 151 & $\mathrm{NR}$ & 151 \\
\hline $\mathrm{U}$ & 848 & 164 & $\mathrm{NR}$ & 160 \\
\hline $\mathrm{Zr}$ & $<63.5$ & $<12.3$ & 31.0 & 31.0 \\
\hline $\mathrm{Radionuclides}$ & & & \\
\hline${ }^{137} \mathrm{Cs}$ & 42,200 & 8,180 & $\mathrm{NR}$ & 8,180 \\
\hline${ }^{90} \mathrm{Sr}$ & 4,920 & 954 & $\mathrm{NR}$ & 954 \\
\hline
\end{tabular}

NA $=$ Not applicable

$\mathrm{NR}=$ Not reported

${ }^{a}$ Kupfer and Winward (1997)

${ }^{\mathrm{b}}$ Calculated by multiplying data in column 2 by the ratio of volumes of waste in tanks 242-BX-111 and BX-112 (32 kgal/165 kgal)

${ }^{\circ}$ Data generated in Section D3.5.1

${ }^{d}$ Data selected from columns 3 or 4

${ }^{\circledR}$ Radionuclides decayed to January 1, 1994.

\section{D3.5.2 Inventory Estimates for BY Tank Farm Salt Cake}

The inventory of components from BY Tank Farm salt cake were calculated from the average component concentrations from tanks 241-BY-105, 241-BY-106, and 241-BY-110 (Table D3-3). The waste volume assumed for this waste type (678 kL [179 kgai]) and the average waste density of $1.71 \mathrm{~g} / \mathrm{mL}$ were used for these calculations. The following is an example calculation for the $\mathrm{Na}$ content in the BY Tank Farm salt cake in tank 241-BX-111.

Na: $\quad 2.13 \mathrm{E}+05 \mu \mathrm{g} / \mathrm{g} \times 1.0 \mathrm{E}-06 \mathrm{~g} / \mu \mathrm{g} \times 1.71 \mathrm{~kg} / \mathrm{L} \times 678 \mathrm{~kL} \times 1,000 \mathrm{~L} / \mathrm{kL}$ $=2.47 \mathrm{E}+05 \mathrm{~kg} \mathrm{Na}$ 
HNF-SD-WM-ER-653

\section{Revision 0}

Table D3-5. Estimated Salt Cake Inventory in Tank 241-BX-111.

\begin{tabular}{|c|c|c|c|c|c|}
\hline Analyte & $\begin{array}{c}\text { Average } \\
\text { concentration } \\
(\mu \mathrm{g} / \mathrm{g})\end{array}$ & $\begin{array}{l}\text { Salt cake } \\
\text { inventory } \\
\text { estimate }^{\mathrm{b}} \\
\cdot(\mathrm{kg})\end{array}$ & Analyte & $\begin{array}{c}\text { Average } \\
\text { concentration } \\
(\mu \mathrm{g} / \mathrm{g})\end{array}$ & $\begin{array}{c}\text { Salt cake } \\
\text { inventory } \\
\text { estimate }^{\mathrm{b}}(\mathrm{kg})\end{array}$ \\
\hline $\mathrm{Al}$ & 17,633 & 20,400 & $\mathrm{NO}_{2}$ & 24,037 & 27,900 \\
\hline $\mathrm{Bi}$ & 55.6 & 64.5 & $\mathrm{PO}_{4}$ & 8,120 & 9,410 \\
\hline $\mathrm{Ca}$ & 308 & 357 & $\mathrm{OH}$ & NR & NR \\
\hline $\mathrm{Cl}$ & 1,736 & 2,010 & $\mathrm{~K}$ & 1,704 & 1,980 \\
\hline $\mathrm{Cr}$ & 1,359 & 1,580 & $\mathrm{Si}$ & 272 & 315 \\
\hline $\mathrm{F}$ & 4,883 & 5,660 & $\mathrm{SO}_{4}$ & 13,433 & 15,600 \\
\hline $\mathrm{Fe}$ & 538 & 624 & $\mathrm{Sr}$ & 64 & 74 \\
\hline $\mathrm{Pb}$ & 82 & 95.1 & $\mathrm{CO}_{3}$ & 97,900 & 114,000 \\
\hline $\mathrm{Mn}$ & 39.1 & 45.3 & TOC & 3,890 & 4,510 \\
\hline $\mathrm{Na}$ & 212,667 & 247,000 & U & 374 & 434 \\
\hline $\mathrm{Ni}$ & 106 & 123 & $\mathrm{Zr}$ & 8.64 & 10.0 \\
\hline $\mathrm{NO}_{3}$ & 335,000 & 388,000 & & & \\
\hline $\begin{array}{c}\text { Radio- } \\
\text { nuclides }\end{array}$ & $\mu \mathrm{Ci} / \mathrm{g}$ & $\mathrm{Ci}$ & $\begin{array}{l}\text { Radio- } \\
\text { nuclides }\end{array}$ & $\mu \mathrm{Ci} / \mathrm{g}$ & $\mathrm{Ci}$ \\
\hline${ }^{137} \mathrm{Cs}$ & 86.2 & 99,900 & ${ }^{239 / 240} \mathrm{Pu}$ & 0.019 & 22 \\
\hline${ }^{90} \mathrm{Sr}$ & 22.9 & 26,500 & & & \\
\hline
\end{tabular}

NR $=$ Not reported

${ }^{2}$ Data from Table D3-3, column 5

${ }^{\mathrm{b}}$ Calculated assuming density $=1.71 \mathrm{~g} / \mathrm{mL}$ and volume $=678 \mathrm{~kL}(179 \mathrm{kgal})$

${ }^{\mathrm{c}}$ Radionuclides decayed to January 1, 1994.

\section{D3.5.2 Tank Inventory Estimate}

The tank inventory estimates were calculated by adding the salt cake component estimate (column 2) with the sludge inventory estimate (column 3) and are reported in column 4. The HDW model inventory estimates are included in column 5 for comparison. 


\section{HNF-SD-WM-ER-653}

\section{Revision 0}

Table D3-6. Inventory Estimate for Tank 241-BX-111 (2 Sheets)

\begin{tabular}{|c|c|c|c|c|}
\hline Analyte & $\begin{array}{c}\text { Salt cake } \\
\text { inventory } \\
\text { estimate }^{\mathrm{a}} .(\mathrm{kg})\end{array}$ & $\begin{array}{l}\text { Engineering-based } \\
\text { sludge inventory } \\
\text { estimate }^{\mathrm{b}}(\mathrm{kg})\end{array}$ & $\begin{array}{c}\text { Engineering-based } \\
\text { tank inventory } \\
\text { estimate }^{c}(\mathrm{~kg})\end{array}$ & $\begin{array}{l}\text { HDW tank } \\
\text { inventory } \\
\text { estimate }^{\mathrm{d}}(\mathrm{kg})\end{array}$ \\
\hline $\mathrm{Al}$ & 20,400 & 2,150 & 22,600 & 42,000 \\
\hline $\mathrm{Bi}$ & 64.5 & 2,760 & 2,820 & 1,250 \\
\hline $\mathrm{Ca}$ & 357 & 396 & 753 & 2,210 \\
\hline $\mathrm{Cl}$ & 2,010 & 167 & 2,180 & 3,110 \\
\hline $\mathrm{Cr}$ & 1,580 & 204 & 1,780 & 1,810 \\
\hline $\mathrm{F}$ & 5,660 & 1,690 & 7,330 & 1,210 \\
\hline $\mathrm{Fe}$ & 624 & 1,490 & 2,110 & 1,820 \\
\hline $\mathrm{Pb}$ & 95.1 & $<52$ & $<147$ & 796 \\
\hline $\mathrm{Mn}$ & 45.3 & 51 & 96.3 & 121 \\
\hline $\mathrm{Na}$ & 247,000 & 13,000 & 260,000 & 203,000 \\
\hline $\mathrm{Ni}$ & 123 & $<0.44$ & 123 & 546 \\
\hline $\mathrm{NO}_{3}$ & 388,000 & 11,900 & 400,000 & 272,000 \\
\hline $\mathrm{NO}_{2}$ & 27,900 & 4,050 & 32,000 & 55,700 \\
\hline $\mathrm{PO}_{4}$ & 9,410 & 9,330 & 18,740 & 14,500 \\
\hline $\mathrm{OH}$ & NR & NR & $\mathrm{NA}$ & 113,000 \\
\hline $\mathrm{K}$ & 1,980 & 74.1 & 2,050 & 1,010 \\
\hline $\mathrm{Si}$ & 315 & 1,320 & 1,640 & 1,660 \\
\hline $\mathrm{SO}_{4}$ & 15,600 & 1,330 & 16,900 & 13,000 \\
\hline $\mathrm{Sr}$ & 74 & 20.8 & 94.8 & 0.213 \\
\hline $\mathrm{CO}_{3}$ & 114,000 & 1,710 & 116,000 & 20,700 \\
\hline TOC & 4,510 & 151 & 4,660 & 4,940 \\
\hline U & 434 & 164 & 598 & 4,180 \\
\hline $\mathrm{Zr}$ & 10.0 & 31.0 & 41.0 & .95 .8 \\
\hline
\end{tabular}


HNF-SD-WM-ER-653

Revision 0

Table D3-6. Inventory Estimate for Tank 241-BX-111 (2 Sheets)

\begin{tabular}{|c|c|c|c|c|}
\hline Analyte & $\begin{array}{c}\text { Salt cake } \\
\text { inventory } \\
\text { estimate }^{\mathrm{a}}(\mathrm{kg})\end{array}$ & $\begin{array}{c}\text { Engineering-based } \\
\text { sludge inventory }^{\text {estimate }^{\mathrm{b}}(\mathrm{kg})}\end{array}$ & $\begin{array}{c}\text { Engineering-based } \\
\text { tank inventory } \\
\text { estimate }^{\mathrm{c}}(\mathrm{kg})\end{array}$ & $\begin{array}{c}\text { HDW tank } \\
\text { inventory } \\
\text { estimate }^{\mathrm{d}}(\mathrm{kg})\end{array}$ \\
\hline \multicolumn{5}{|l|}{} \\
\hline Radionuclides $^{\mathrm{e}}(\mathrm{Ci})$ & 8,180 & 108,000 & 150,000 \\
\hline${ }^{137} \mathrm{Cs}$ & 99,900 & 954 & 27,400 & 88,000 \\
\hline${ }^{90} \mathrm{Sr}$ & 26,500 &
\end{tabular}

HDW $=$ Hanford Defined Waste

NA $=$ Not applicable

$\mathrm{NR}=$ Not reported

${ }^{a}$ Data from Table D3-5, columns 3 and 6

${ }^{b}$ Data from Table D3-4, column 5

${ }^{\circ}$ Data is the sum of columns 2 and 3 in this table

${ }^{d}$ Agnew et al. (1996)

' Radionuclides decayed to January 1,.1994.

\section{D3.6 EVALUATION SUMMARY}

The lack of sample-based inventory data adds considerable uncertainty to estimation of chemical and radionuclide inventories for tank 241-BX-111. The use of analytical-based composition data from other tanks seems the most viable approach for tank 241-BX-111. However, the largest uncertainty pertains to correctly predicting the relative proportions of the waste types in the tank and assuming that the analytical basis for the inventories in one tank can be extrapolated correctly to another tank. For the $1 \mathrm{C}$ waste type, the latter concern is reduced somewhat since there is evidence based on at least two other tanks that the tank waste analyses are representative of the $\mathrm{BiPO}_{4} \mathrm{IC}$ flowsheet. However, there is considerable variation in component concentrations (particularly for minor components) for the three tanks that represent (241-BY-105, 241-BY-106, and 241-BY-110) the BY Tank Farm salt cake.

Estimated inventories from this evaluation for selected components are compared with the HDW model-based inventories in Table D3-6. Estimated inventories for the $1 \mathrm{C}$ waste component (based on tank 241-BX-112 sample analyses) and the average BY Tank Farm salt cake were added together to provide the total tank inventory estimate. Comments and observations regarding these inventories are provided by component in the following text.

Aluminum. The aluminum inventory estimated by this assessment is about 50 percent of that predicted by the HDW model. The largest contribution of aluminum is from the BY Tank Farm salt cake rather than $1 \mathrm{C}$ waste. The aluminum concentrations in all three comparison samples were less than that for the HDW model BYSltCk. Additionally, the variation in aluminum concentration among the three samples was quite small. 
Bismuth. The bismuth inventory estimated by this evaluation is approximately twice that provided by the HDW model. The HDW model assumes that a significant portion of the bismuth does not precipitate with the solids, with the soluble fraction being sent to cribs.

Chromium. The chromium inventory estimated from this assessment is about the same as that predicted by the HDW model. However, this is coincidental since the HDW model assumes that none of the chromium in the $1 \mathrm{C}$ waste precipitates with the solids, whereas this assessment reflects sample analyses that indicate essentially all of the chromium reports to the solids. The total chromium content for the two estimates is comparable, however, since the chromium concentration in the BYSltCk defined waste is higher than that for the BY Tank Farm salt cake samples.

Fluoride. The fluoride inventory predicted by this assessment is approximately six times higher than the HDW inventory. Analytical data for tanks 241-BX-112 and 241-T-104 show that a major portion of the fluoride in $1 \mathrm{C}$ waste is partitioned to the solids, whereas, the HDW model assumes that no fluoride partitions to the solids. In addition, the sample analyses for the three BY Tank Farm (241-BY-105, 241-BY-106, and 241-BY-110) salt cake tanks consistently show six to seven times higher fluoride concentrations that predicted for the HDW model BYSitCk.

Total Hydroxide. Once the best-basis inventories were determined, the hydroxide inventory was calculated by performing a charge balance with valences of other analytes. In some cases, this approach required that other analyses (e.g., sodium or nitrate) inventories be adjusted to achieve the charge balance. No adjustments were required in this best-basis estimate. This charge balance approach is consistent with that used by Agnew et al. (1997).

Iron. The iron inventory estimated by this assessment is approximately the same as the HDW model prediction. The HDW model assumes essentially all iron precipitates with the $1 \mathrm{C}$ waste but analytical evidence for tanks $241-\mathrm{BX}-112$ and $241-\mathrm{T}-104$ indicates that approximately 75 percent precipitates. However, the iron concentrations for the HDW model defined waste BYSltCk is slightly higher than for the average for the three BY Tank Farm (241-BY-105, 241-BY-106, and 241-BY-110) salt cake samples.

Sodium. This assessment predicts a 30 percent higher sodium inventory than predicted by the HDW model. This is due entirely to the consistently higher sodium concentrations found for the BY Tank Farm salt cake tank samples than for the HDW model BYSItCk.

Nitrate. Consistently higher concentrations of nitrate where found for the three BY Tank Farm (241-BY-105, 241-BY-106, and 241-BY-110) salt cake samples than predicted for the HDW model BYSltCk defined waste.

Nitrite. This assessment predicts only half of the inventory for nitrite than predicted by the HDW model. This is due to the consistently lower nitrite concentrations found for the three BY Tank Farm (241-BY-105, 241-BY-106, and 241-BY-110) salt cake tank samples than for the HDW model BYSltCk defined waste. 
HNF-SD-WM-ER-653

Revision 0

Phosphate. The phosphate inventory estimated by this assessment is about 25 percent higher than the HDW model prediction. The phosphate concentrations for the three BY Tank Farm (241-BY-105, 241-BY-106, and 241-BY-110) salt cake samples were twice that for the HDW model BYSItCk. However, the HDW model predicts a higher phosphate inventory contribution from the $1 \mathrm{C}$ wastes primarily due to the higher phosphate concentration for the HDW model 1C defined waste than assumed for the Schneider (1951) process flowsheet (see Table D3-1).

Uranium. The HDW model predicts the tank waste uranium inventory to be seven fold higher than estimated by this assessment. Essentially the entire uranium contribution is from the BYSltCk. However, the uranium concentrations in the tank samples that represent BY Tank Farm salt cake average approximately ten times lower than for the BYSItCK defined waste. This assessment concludes that the sample data provided the best basis for estimating the uranium inventory. 
HNF-SD-WM-ER-653

Revision 0

\section{D4.0 DEFINE THE BEST-BASIS AND ESTABLISH COMPONENT INVENTORIES}

An effort is underway to provide waste inventory estimates that will serve as the standard for characterization for the various waste management activities (Hodgson and LeClair 1996). As part of this effort, an evaluation of available chemical information for tank 241-BX-111 was performed including the following:

- Analytical data from two tanks (241-T-104 and 241-BX-112 [DiCenso et al. 1994 and Kupfer and Winward 1997]) that represent the $\mathrm{BiPO}_{4}$ process $1 \mathrm{C}$ waste type in tank 241-BX-111.

- Analytical data from three tanks (241-BY-105, 241-BY-106, and 241-BY-110 [Simpson et al. 1995, Bell et al. 1996, and Simpson et al. 1996]) that contain the same salt cake waste type that is in tank 241-BX-111. The salt cake in tank 241BX-111 resulted from evaporation of supernatants in the BY Tank Farm using intank heaters (ITS campaigns).

- Inventory estimates generated by the HDW model (Agnew et al. 1996).

There are no tank sample data for tank 241-BX-111 that can be used to estimate tank waste component inventories. The results from this engineering assessment support using an estimated inventory based primarily on the analytical results for tank 241-BX-112 (for 1C waste), and tanks 241-BY-105, 241-BY-106, and 241-BY-110 (for BY Tank Farm salt cake) for the following reasons:

- Evaluation of waste transaction data support the Agnew et al. (1996) basis that tank 241-BX-111 contains a mixture of 1C waste and salt cake from ITS operations in BY Tank Farm.

- The analytical results from tanks $241-\mathrm{T}-104$ and $241-\mathrm{BX}-112$, which contain only $1 \mathrm{C}$ waste, correlate well with predicted inventories for these tanks based on process flowsheets. Assessments have shown that the analytical-based compositions for these tanks can be extrapolated to the same waste type in other tanks, particularly if the tanks are in a cascade arrangement. This assumption must be considered tenuous at this time with resolution provided by possible future sampling of tank 241-BX-111.

- The concentrations of components from waste solids for three tanks (241-BY-105, 241-BY-106, and 241-BY-110) containing salt cake in the BY Tank Farm are reasonably consistent among themselves, and with predicted salt cake from the HDW model (BYSltCk). The sample data for the BY Tank Farm tanks are expected to be representative of the salt cake in tank 241-BX-111 since the source for the salt cake is from the ITS evaporation campaign in BY Tank Farm. 
HNF-SD-WM-ER-653

\section{Revision 0}

Best-basis inventory estimates for tank 241-BX-111 are presented in Tables D4-1 and D4-2. The quality of the estimate for chemical and radionuclide components is considered low since the inventories are extrapolated from data from other tanks. The HDW model bases are used as best basis where there was no sample basis. Radionuclide curie values are decayed to January 1, 1994.

Best-basis tank inventory values were derived for 46 key radionuclides (as defined in Section 3.1 of Kupfer et al. 1997), all decayed to a common report date of January 1, 1994. Often, waste sample analyses were only reported for total beta, total alpha, ${ }^{90} \mathrm{Sr},{ }^{137} \mathrm{Cs}$, ${ }^{239 / 240} \mathrm{Pu}$, and total uranium, while other key radionuclides such as ${ }^{60} \mathrm{Co},{ }^{99} \mathrm{Tc},{ }^{129} \mathrm{I},{ }^{154} \mathrm{Eu}$, ${ }^{155} \mathrm{Eu}$, and ${ }^{241} \mathrm{Am}$, etc., were infrequently reported. For this reason it has been necessary to derive most of the 46 key radionuclides by computer models. These models estimate radionuclide activity in batches of reactor fuel, account for the split of radionuclides to various separations plant waste streams, and track their movement with tank waste transactions. (These computer models are described in Kupfer et al. 1997, Section 6.1 and in Watrous and Wootan 1997.)

Model generated values for radionuclides in any of 177 tanks are reported in the HDW Rev. 4 model results (Agnew et al. 1997). The best-basis value for any one analyte may be either a model result or a sample or engineering assessment-based result if available. (No attempt has been made to ratio or normalize model results for all 46 radionuclides when values for measured nuclides disagree with the model.) For a discussion of typical error between model derived values and sample derived values, see Kupfer et al. 1997, Section 6.1.10.

Best-basis tables for chemicals and only four radionuclides $\left({ }^{90} \mathrm{Sr},{ }^{137} \mathrm{Cs}, \mathrm{Pu}\right.$, and $\left.\mathrm{U}\right)$ were being generated in 1996, using values derived from an earlier version (Rev. 3) of the HDW model. When values for all 46 radionuclides became available in Rev. 4 of the HDW model, they were merged with draft best-basis chemical inventory documents. Defined scope of work in FY 1997 did not permit Rev. 3 chemical values to be updated to Rev. 4 chemical values.

The inventory values reported in Tables D4-1 and D4-2 are subject to change. Refer to the Tank Characterization Database (TCD) for the most current inventory values. 
HNF-SD-WM-ER-653

Revision 0

Table D4-1. Sample-based Best-Basis Inventory Estimate for Nonradioactive

Components in Tank 241-BX-111 (Effective January 31, 1997). (2 sheets)

\begin{tabular}{|c|c|c|c|}
\hline Analyte & $\begin{array}{l}\text { Total inventory } \\
(\mathrm{kg})\end{array}$ & $\begin{array}{c}\text { Basis } \\
(\mathrm{S}, \mathrm{M}, \mathrm{C}, \text { or } \mathrm{E})^{1}\end{array}$ & Comment \\
\hline $\mathrm{Al}$ & 22,600 & E & \\
\hline $\mathrm{Bi}$ & 2,820 & $\mathrm{E}$ & \\
\hline $\mathrm{Ca}$ & 753 & $\mathrm{E}$ & \\
\hline $\mathrm{Cl}$ & 2.180 & $\mathrm{E}$ & \\
\hline $\mathrm{TIC}$ as $\mathrm{CO}_{3}$ & 116,000 & $\mathrm{E}$ & \\
\hline $\mathrm{Cr}$ & 1,780 & $\mathrm{E}$ & \\
\hline $\mathrm{F}$ & 7.330 & $\mathrm{E}$ & \\
\hline $\mathrm{Fe}$ & 2,110 & E & \\
\hline $\mathrm{Hg}$ & 6.33 & $\mathrm{M}$ & \\
\hline $\mathrm{K}$ & 2,050 & $\mathrm{E}$ & \\
\hline $\mathrm{La}$ & 0.304 & $\mathrm{M}$ & \\
\hline $\mathrm{Mn}$ & 96.3 & $\mathrm{E}$ & \\
\hline $\mathrm{Na}$ & 260,000 & $\mathrm{E}$ & \\
\hline $\mathrm{Ni}$ & 123 & $\mathrm{E}$ & \\
\hline $\mathrm{NO}_{2}$ & 32,000 & $\mathrm{E}$ & \\
\hline $\mathrm{NO}_{3}$ & 400,000 & E & \\
\hline $\mathrm{OH}_{\text {TOTAI }}$ & 26,400 & $\mathrm{C}$ & \\
\hline $\mathrm{Pb}$ & $<147$ & $\mathrm{E}$ & \\
\hline $\mathrm{PO}_{4}$ & 18,740 & $\mathrm{E}$ & \\
\hline $\mathrm{Si}$ & 1,640 & $E$ & \\
\hline $\mathrm{SO}_{4}$ & 16,900 & $\mathrm{E}$ & \\
\hline $\mathrm{Sr}$ & 95 & $\mathrm{E}$ & \\
\hline TOC & 4,660 & $\mathrm{E}$ & \\
\hline $\mathrm{U}_{\text {TaraI }}$ & 598 & $\mathrm{E}$ & \\
\hline $\mathrm{Zr}$ & 41 & $E$ & \\
\hline
\end{tabular}

${ }^{1} \mathrm{~S}=$ Sample-based

M = Hanford Defined Waste model-based, Agnew et al. (1996)

$\mathrm{E}=$ Engineering assessment-based

- $\mathrm{C}=$ Calculated by charge balance; includes oxides as "hydroxide" not including $\mathrm{CO}_{3}, \mathrm{NO}_{2}, \mathrm{NO}_{3}, \mathrm{PO}_{4}, \mathrm{SO}_{4}$, and $\mathrm{SiO}_{3}$. 
HNF-SD-WM-ER-653

Revision 0

Table D4-2. Best-Basis Inventory Estimate for Radioactive Components in Tank 241-BX-

111 Decayed to January 1, 1994 (Effective January 31, 1997). (2 Sheets)

\begin{tabular}{|c|c|c|c|}
\hline Analyte & $\begin{array}{c}\text { Total inventory } \\
\text { (Ci) }\end{array}$ & $\begin{array}{c}\text { Basis } \\
(\mathrm{S}, \mathrm{M}, \text { or } E)^{1}\end{array}$ & Comment \\
\hline${ }^{3} \mathrm{H}$ & 88.5 & M & \\
\hline${ }^{14} \mathrm{C}$ & 23 & M & \\
\hline${ }^{59} \mathrm{Ni}$ & 2.46 & M & \\
\hline${ }^{60} \mathrm{Co}$ & 21.6 & M & \\
\hline${ }^{63} \mathrm{Ni}$ & 244 & M & \\
\hline${ }^{79} \mathrm{Se}$ & 1.94 & M & \\
\hline${ }^{90} \mathrm{Sr}$ & 27,400 & $\mathrm{E}$ & \\
\hline${ }^{90} \mathrm{Y}$ & 27,400 & $\mathrm{E}$ & Referenced to ${ }^{90} \mathrm{Sr}$ \\
\hline${ }^{93 m} \mathrm{Nb}$ & 6.75 & M & \\
\hline${ }^{93} \mathrm{Zr}$ & 9.34 & M & \\
\hline${ }^{99} \mathrm{Tc}$ & 128 & M & \\
\hline${ }^{106} \mathrm{Ru}$ & 0.0043 & M & \\
\hline${ }^{113 m} \mathrm{Cd}$ & 49.4 & $\mathrm{M}$ & \\
\hline${ }^{125} \mathrm{Sb}$ & 96.6 & M & . \\
\hline${ }^{126} \mathrm{Sn}$ & 2.89 & M & \\
\hline${ }^{129} \mathrm{I}$ & 0.249 & $\mathrm{M}$ & \\
\hline${ }^{134} \mathrm{Cs}$ & 1.05 & M & \\
\hline${ }^{137} \mathrm{~m} \mathrm{Ba}$ & 102,000 & $\mathrm{E}$ & Referenced to ${ }^{137} \mathrm{Cs}$ \\
\hline${ }^{137} \mathrm{Cs}$ & 108,000 & $\mathrm{E}$ & \\
\hline${ }^{151} \mathrm{Sm}$ & 6,690 & M & \\
\hline${ }^{152} \mathrm{Eu}$ & 3.04 & M & \\
\hline${ }^{154} \mathrm{Eu}$ & 364 & M & \\
\hline${ }^{155} \mathrm{Eu}$ & 184 & M & \\
\hline${ }^{226} \mathrm{Ra}$ & $9.35 \mathrm{E}-05$ & M & \\
\hline${ }^{227} \mathrm{Ac}$ & 0.00132 & $\mathbf{M}$ & \\
\hline${ }^{228} \mathrm{Ra}$ & 1.15 & M & \\
\hline${ }^{229} \mathrm{Th}$ & 0.0266 & M & \\
\hline${ }^{231} \mathrm{~Pa}$ & 0.00679 & M & \\
\hline
\end{tabular}


HNF-SD-WM-ER-653

Revision 0

Table D4-2. Best-Basis Inventory Estimate for Radioactive Components in Tank 241-BX-

111 Decayed to January 1, 1994 (Effective January 31, 1997). (2 Sheets)

\begin{tabular}{|c|c|c|c|}
\hline Analyte & $\begin{array}{c}\text { Total inventory } \\
(\mathrm{Ci})\end{array}$ & $\begin{array}{c}\text { Basis } \\
(\mathrm{S}, \mathrm{M}, \text { or E })^{\mathrm{I}}\end{array}$ & Comment \\
\hline${ }^{232} \mathrm{Th}$ & 0.0425 & $\mathrm{M}$ & \\
\hline${ }^{232} \mathrm{U}$ & 6.42 & $\mathrm{M}$ & \\
\hline${ }^{233} \mathrm{U}$ & 24.6 & $\mathrm{M}$ & \\
\hline${ }^{234} \mathrm{U}$ & 3.51 & $\mathrm{M}$ & \\
\hline${ }^{235} \mathrm{U}$ & 0.143 & $\mathrm{M}$ & \\
\hline${ }^{236} \mathrm{U}$ & 0.0761 & $\mathrm{M}$ & \\
\hline${ }^{237} \mathrm{~Np}$ & 0.431 & $\mathrm{M}$ & \\
\hline${ }^{238} \mathrm{Pu}$ & 1.77 & $\mathrm{M}$ & \\
\hline${ }^{238} \mathrm{U}$ & 5.44 & $\mathrm{M}$ & \\
\hline${ }^{239} \mathrm{Pu}$ & 68.2 & $\mathrm{M}$ & \\
\hline${ }^{240} \mathrm{Pu}$ & 11.2 & $\mathrm{M}$ & \\
\hline${ }^{241} \mathrm{Am}$ & 30.2 & $\mathrm{M}$ & \\
\hline${ }^{241} \mathrm{Pu}$ & 126 & $\mathrm{M}$ & \\
\hline${ }^{242} \mathrm{Cm}$ & $5.17 \mathrm{E}-04$ & $\mathrm{M}$ & \\
\hline${ }^{242} \mathrm{Pu}$ & $6.06 \mathrm{E}-04$ & $\mathrm{M}$ & \\
\hline${ }^{243} \mathrm{Am}$ & 0.00104 & $\mathrm{M}$ & \\
\hline${ }^{243} \mathrm{Cm}$ & $1.06 \mathrm{E}-05$ & $\mathrm{M}$ & \\
\hline${ }^{244} \mathrm{Cm}$ & $1.46 \mathrm{E}-04$ & $\mathrm{M}$ & \\
\hline${ }^{24} \mathrm{~S}$ & & & \\
\hline $\mathrm{S}$ & & & \\
\hline
\end{tabular}

${ }^{\text {is }}=$ Sample-based

$M=$ Hanford Defined Waste model-based, Agnew et al. (1997)

$\mathrm{E}=$ Engineering assessment-based. 
HNF-SD-WM-ER-653

Revision 0

This page intentionally left blank. 
HNF-SD-WM-ER-653

Revision 0

\section{D5.0 APPENDIX D REFERENCES}

Agnew, S. F., R. A. Corbin, T. B. Duran, K. A. Jurgensen, T. P. Ortiz, and B. L. Young, 1995, Waste Status and Transaction Record Summary (WSTRS Rev. 2),

WHC-SD-WM-TI-615, -614, -669, -689, Rev. 2, Los Alamos National Laboratory, Los Alamos, New Mexico.

Agnew, S. F., J. Boyer, R. A. Corbin, T. B. Duran, J. R. FitzPatrick, K. A. Jurgensen, T. P. Ortiz, and B. L. Young, 1996, Hanford Tank Chemical and Radionuclide Inventories: HDW Model Rev. 3, LA-UR-96-858, Los Alamos National Laboratory, Los Alamos, New Mexico.

Agnew, S. F., J. Boyer, R. A. Corbin, T. B. Duran, J. R. FitzPatrick, K. A. Jurgensen, T. P. Ortiz, and B. L. Young, 1997, Hanford Tank Chemical and Radionuclide Inventories: HDW Model Rev. 4, LA-UR-96-3860, Los Alamos National Laboratory, Los Alamos, New Mexico.

Anderson, J. D., 1990, A History of the 200 Area Farms, WHC-MR-0132, Westinghouse Hanford Company, Richland, Washington.

Bell, K. E.; J. D. Franklin, J. L. Stroup, J. L. Huckaby, 1996, Tank Characterization Report for Single-Shell Tank 241-BY-106, WHC-SD-WM-ER-616, Rev. 0, Westinghouse Hanford Company, Richland, Washington.

Brevick, C. H., R. L. Newell, and J. W. Funk, 1996, Historical Tank Content Estimate for the Northeast Quadrant of the Hanford 200 East Area, WHC-SD-WM-ER-349, Rev. 1, Westinghouse Hanford Company, Richland, Washington.

DiCenso, A. T., L. C. Amato, J. D. Franklin, G. L. Nuttal, K. W. Johnson (LANL), and B. C. Simpson (WHC), 1994, Tank Characterization Report for Single-Shell Tank 241-T-104, WHC-SD-WM-ER-372, Rev. 0, Westinghouse Hanford Company, Richland, Washington.

Hanlon, B. M., 1996, Waste Tank Summary Report for Month Ending May 31, 1996, WHC-EP-182-99, Westinghouse Hanford Company, Richland, Washington

Hill, J. G., G. S. Anderson, and B. C. Simpson, 1995, The Sort on Radioactive Waste Type Model: A Method to Sort Single-Shell Tanks into Characteristic Groups, PNL-9814, Rev. 2, Pacific Northwest Laboratory, Richland, Washington.

Hodgson, K. M., and M. D. LeClair, 1996, Work Plan for Defining a Standard Inventory Estimate for Wastes Stored in Hanford Site Underground Tanks, WHC-SD-WM-WP-311, Rev. 1, Lockheed Martin Hanford Corporation, Richland, Washington. 
Kupfer, M. J., A. L. Boldt, B. A. Higley, K. M. Hodgson, L. W. Shelton, B. C. Simpson, and R. A. Watrous (LMHC), S. L. Lambert, and D. E. Place (SESC), R. M. Orme (NHC), G. L. Borsheim (Borsheim Associates), N. G. Colton (PNNL), M. D. LeClair (SAIC), R. T. Winward (Meier Associates), and W. W. Schulz (W2S Corporation), 1997, Standard Inventories of Chemicals and Radionuclides in Hanford Site Tank Wastes; HNF-SD-WM-TI-740, Rev. 0, Lockheed Martin Hanford Corporation, Richland, Washington.

Kupfer, M. J., and R. T. Winward (Meier Associates), 1997, Tank Characterization Report for Single-Shell Tank 24I-BX-112, WHC-SD-WM-ER-602, Rev. 0A, Lockheed Martin Hanford Corporation, Richland, Washington.

Schneider, K. L., 1951, Flow Sheets and Flow Diagrams of Precipitation Separations Process, HW-23043, Hanford Atomic Products Operation, Richland, Washington.

Simpson, B. C., J. G. Field, L. M. Sasaki, 1996a, Tank Characterization Report for SingleShell Tank 241-BY-105, WHC-SD-WM-ER-598, Rev. 0, Westinghouse Hanford Company, Richland, Washington.

Simpson, B. C., R. D. Cromar, R. D. Schreiber, 1996b, Tank 24l-BY-110 Characterization Report, WHC-SD-WM-ER-591, Rev. 0, Westinghouse Hanford Company, Richland, Washington.

Watrous, R. A., and D. W. Wootan, 1997, Activity of Fuel Batches Processed Through Hanford Separations Plants, 1944 Through 1989, HNF-SD-WM-TI-794, Rev. 0, Lockheed Martin Hanford Corporation, Richland, Washington. 